УДК 633.11:631.526.3

DOI https://doi.org/10.32848/agrar.innov.2021.5.18

\title{
ДОСЛІДЖЕННЯ ПРОДУКТИВНОСТІ СОРТОВОГО СКЛАДУ ПШЕНИЦІ ОЗИМОЇ В УМОВАХ ПІВДЕННОГО СТЕПУ УКРАЇНИ
}

\author{
БЕРДНІКОВА О.Г. - кандидат сільськогосподарських наук, доцент \\ http://orcid.org/0000-0002-7217-1672 \\ Херсонський державний аграрно-економічний університет \\ КУЧЕРАК Е.М. - здобувач \\ http://orcid.org/0000-0002-9853-7724 \\ Херсонський державний аграрно-економічний університет
}

Постановка проблеми. За продовольчим значенням і масштабам виробництва чільне місце займає пшениця. Упровадження нових сортів озимої пшениці у виробництво - шлях до збільшення рентабельності її вирощування Озима пшениця - основна продовольча культура в нашій державі. Саме ії̈ врожайність і рентабельність вирощування значною мірою визначають ступінь добробуту сільськогосподарських товаровиробників. На превеликий жаль, середня врожайність цієї культури в Україні в 2,5 рази нижча, ніж у країнах Західної Європи. Такий стан речей зумовлений багатьма чинниками, одним з яких $є$ використання для посівів насіння невисоких репродукції та застарілих сортів, що не відповідають сучасним вимогам високоінтенсивного землеробства. У сучасних умовах, коли сортооновлення відбувається протягом 6-8 років, дослідження у селекційних центрах світу і України спрямовані на створення нових високопродуктивних сортів із високим потенціалом урожайності, підвищеною стійкістю до комплексу хвороб, несприятливих погодних умов та високими показниками якості зерна. Саме тісна співпраця спеціалістів агрофірми «Сади України» з провідними селекційними центрами (Селекційно-генетичним інститутом, Інститутом фізіології та генетики рослин, Миронівським інститутом пшениці, селекційним інститутом Краснодару) зумовила отримання високих щорічних урожаїв.

Аналіз останніх досліджень і публікацій. Підвищення виробництва продовольчого зерна м'якої пшениці значною мірою залежить від потенційних можливостей сорту і ступеню її реалізації за різних кліматичних умов та технологій вирощування. Тому ідентифрікація сортового складу цієї культури з різними адаптивними властивостями і типом розвитку за параметрами екологічної пластичності та стабільності врожайності є надзвичайно актуальною і має велике практичне значення.

У Південному Степу України це біологічне явище сприяє активному весняному відростанню рослин за скороченого дня, що забезпечує добре використання вологи й інтенсивне формування біологічного врожаю [2; 3]. Деякі сорти озимої пшениці, які характеризуються цими ознаками, в окремі роки за відповідних умов зовнішнього середовища ведуть себе як «умовні дворучки», це дає можливість з успіхом їх використовувати за пізніх строків сівби, де «типово» озимі сорти пшениці затримують розвиток і значно знижують потенційну продуктивність. Використання позитивного ефекту цієї взаємодії у виробничих умовах шляхом оптимізації сортового складу пшениці до конкретних агроекологічних умов і впровадження у виробництво сортів дворучок пшениці як страхової культури, безумовно, слугуватиме підвищенню конкурентної здатності сортів пшениці різного типу розвитку.

Основною метою досліджень було визначення продуктивності сортів пшениці озимої як в умовах зрошення, так і без зрошення.

Результати досліджень. Сорт необхідно розглядати в аспекті його реакції на екологічні умови і здатності реалізувати генетичний матеріал у конкретному екологічному регіоні. Кожен сорт може мати свій набір лімітуючих урожайність чинників за умов стресових ситуацій. Нами проведено оцінку сортів озимої пшениці Селекційно-генетичного інституту УААН (Одеса), Краснодарського науково-дослідного інституту сільського господарства (РФ), Інституту землеробства Південного регіону УААН (Херсон).

Озима пшениця досить стійка до понижених температур. За достатнього загартування озима пшениця може витримувати взимку температур до $-25^{\circ} \mathrm{C}$. За недостатнього загартування може пошкоджуватися морозами $\left(14-17^{\circ} \mathrm{C}\right)$.

На морозостійкість озимої пшениці мають вплив генетичні особливості сорту, терміни сівби, фраза, в якій пшениця увійшла в зиму, вміст цукрів у вузлі кущіння, умови зовнішнього середовища.

Узимку від згубного впливу низьких температур пшеницю оберігає сніговий покрив. За відсутності снігового покриву пшениця істотно пошкоджується здебільшого при температурі $-18-19{ }^{\circ} \mathrm{C}$. Окрім низьких температур, озима пшениця взимку може зазнавати негативного впливу льодової кірки, випирання та випрівання.

Більшою зимостійкістю вирізняються сорти, для яких характерний тривалий період яровизації - 40 і більше днів. Краще зимують посіви пшениці, висіяні в оптимальні строки, рослини яких нараховують три пагони, уміст цукрів у вузлі кущіння становить понад 25\%. Цьому сприяють оптимальні терміни сівби, достатнє забезпечення рослин вологою, теплом і елементами живлення, достатнє загартування рослин.

Сорти озимої пшениці мали високий рівень збереження рослин за зимовий період.

Дані таблиці показують, що високу зимостійкість мають усі сорти за винятком Одеської 267, для цього 
сорту зимостійкість рослин становила 78\%. У цілому раннє колосіння відзначене у сорту Дріада, пізніше на 2-5 днів ця фраза наставала у сорту Баграт.

У середньому за рік досліджень вегетаційний період тривав від 281 до 288 днів. Більш коротким він був для сортів Одеська 267 та Баграт. Сорти Таня, Калим та Дріада 1 вегетували на 5-8 днів більше.

Як свідчать дані табл. 1, усі сорти, що вивчалися, мали високу стійкість як проти вилягання, так і до обсипання, поникання колосу та його ламкості. Усі ці показники впливали на врожай зерна досліджуваних сортів озимої пшениці та її структуру.

Деякі сорти (Баграт, Таня) мали добре виражений генетичний захист від шкідливих патогенів.

Умови вирощування озимої пшениці дали змогу подовжити міжфазний період колосіння - повної стиглості, що в подальшому значно вплинуло на рівень продуктивності озимої пшениці. Вегетаційний період та тривалість міжфазних періодів у озимої пшениці представлено в табл. 4.

Виходячи з даних табл. 4, в умовах без зрошення найкоротший період «сходи - повна стиглість» мав сорт Баграт (еліта) - 265 днів. Це на п'ять днів менше, ніж у стандарту Одеська 267. Усі інші сорти мали незначну різницю порівняно зі стандартом.

В умовах зрошення сорти Таня еліта, Калим еліта та Баграт еліта мали найкоротший період «сівба повна стиглість» - 275 днів. Це на вісім днів менше, ніж у стандарту.

Як видно з табл. 4, зрошення суттєво збільшувало період вегетації озимої пшениці - від 10 до 18 днів.

Урожайність рослин $є$ інтегральним показником, що формується за участю окремих кількісних ознак, тому прогноз можливостей підвищення продуктивності значною мірою залежить від знання основних закономірностей фрормування врожаю, сутності зв'язку між окремими компонентами та їхнім впливом на загальну врожайність.

Урожайність повинна розглядатися в розрізі окремих компонентів, що беруть участь у її формуванні, оскільки кожний із них виявляється часто незалежно й є результатом генетичної взаємодії багатьох чинників та агроекологічних умов.

Елементи продуктивності можуть до деякої міри компенсуватися іншими компонентами, що формуються у більш сприятливих умовах на наступних етапах органогенезу.

Для одержання гарантованого високого рівня врожаю зерна озимої пшениці необхідно управляти формуванням кожного елементу продуктивності та орієнтувати технологію на створення відповідної, чітко визначеної структури посіву на запланований урожай.

Структуру врожаю озимої пшениці представлено в табл. 5.

Кількість продуктивних стебел формується починаючи з I по VIII етапи органогенезу і залежить від числа рослин на одиницю площі й їх кущистості. При цьому початковий (осінній) період вегетації озимої пшениці $\epsilon$ вирішальним у формуванні продуктивного стеблостою посівів. У цей час з'являються сходи, визначаються густота посіву та морфобіотип рослин.
Таблиця 1 - Оцінка перезимівлі рослин сортів озимої пшениці

\begin{tabular}{|l|l|c|c|c|}
\hline $\begin{array}{c}\text { № } \\
\text { n/n }\end{array}$ & Сорт & $\begin{array}{c}\text { Стан посівів } \\
\text { восени, } \\
\text { (на 8 листо- } \\
\text { пада), бал }\end{array}$ & $\begin{array}{c}\text { Стан посівів } \\
\text { весною } \\
\text { (на 15 берез- } \\
\text { ня), бал }\end{array}$ & $\begin{array}{c}\text { Оцінка } \\
\text { перези- } \\
\text { мівлі, \% }\end{array}$ \\
\hline 1 & Одеська 267 & 9 & 8 & 78 \\
\hline 2 & Таня еліта & 9 & 8 & 87 \\
\hline 3 & Калим еліта & 9 & 8 & 87 \\
\hline 4 & Баграт (еліта) & 9 & 8 & 86 \\
\hline 5 & Дріада 1 & 9 & 8 & 89 \\
\hline
\end{tabular}

Таблиця 2 - Оцінка стійкості сортів до обсипання, поникання та ламкості колосу, бал

\begin{tabular}{|l|l|c|c|c|}
\hline $\begin{array}{c}\text { № } \\
\mathbf{n} / \mathbf{n}\end{array}$ & Сорт & $\begin{array}{c}\text { Стійкість } \\
\text { до } \\
\text { обсипання }\end{array}$ & $\begin{array}{c}\text { Стійкість до } \\
\text { поникання } \\
\text { колосу }\end{array}$ & $\begin{array}{c}\text { Стійкість } \\
\text { до ламкості } \\
\text { колосу }\end{array}$ \\
\hline 1 & Одеська 267 & 9 & 9 & 9 \\
\hline 2 & Таня еліта & 9 & 9 & 9 \\
\hline 3 & Калим еліта & 9 & 9 & 9 \\
\hline 4 & Баграт (еліта) & 9 & 9 & 9 \\
\hline 5 & Дріада 1 & 9 & 9 & 9 \\
\hline
\end{tabular}

Таблиця 3 - Ураження сортів озимої пшениці грибковими захворюваннями

\begin{tabular}{|l|c|c|}
\hline \multirow{2}{*}{ Сорт } & \multicolumn{2}{|c|}{$\begin{array}{c}\text { Ураження рослин грибковими } \\
\text { захворюваннями, \% }\end{array}$} \\
\cline { 2 - 3 } & бура іржа & борошниста роса \\
\hline Одеська 267 & $15,0 \pm$ & $20,4 \pm$ \\
\hline Таня еліта & $12,6 \pm$ & $15,4 \pm$ \\
\hline Калим еліта & $25,8 \pm$ & $38,0 \pm$ \\
\hline Баграт (еліта) & $8,1 \pm$ & $14,8 \pm$ \\
\hline Дріада 1 & $20,4 \pm$ & $20,5 \pm$ \\
\hline
\end{tabular}

Таблиця 4 - Вегетаційний період та тривалість міжфразних періодів у сортів озимої пшениці

\begin{tabular}{|c|c|c|c|c|c|}
\hline 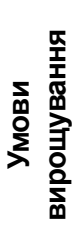 & 훙 & 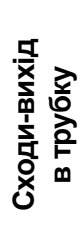 & 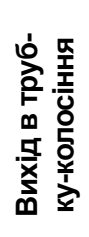 & 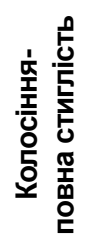 & 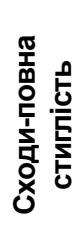 \\
\hline \multirow{5}{*}{ 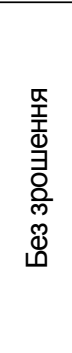 } & $\begin{array}{c}\text { Одеська } \\
267\end{array}$ & 218 & 17 & 35 & 270 \\
\hline & $\begin{array}{l}\text { Таня } \\
\text { еліта }\end{array}$ & 220 & 17 & 34 & 271 \\
\hline & $\begin{array}{l}\text { Калим } \\
\text { еліта }\end{array}$ & 216 & 17 & 34 & 267 \\
\hline & $\begin{array}{l}\text { Баграт } \\
\text { (еліта) }\end{array}$ & 214 & 16 & 35 & 265 \\
\hline & Дріада 1 & 220 & 16 & 34 & 270 \\
\hline \multirow{5}{*}{ 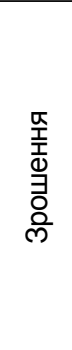 } & $\begin{array}{c}\text { Одеська } \\
267\end{array}$ & 218 & 15 & 50 & 283 \\
\hline & $\begin{array}{l}\text { Таня } \\
\text { еліта } \\
\end{array}$ & 216 & 14 & 45 & 275 \\
\hline & $\begin{array}{l}\text { Калим } \\
\text { еліта }\end{array}$ & 214 & 14 & 47 & 275 \\
\hline & $\begin{array}{l}\text { Баграт } \\
\text { (еліта) }\end{array}$ & 214 & 13 & 48 & 275 \\
\hline & Дріада 1 & 220 & 16 & 52 & 288 \\
\hline
\end{tabular}


Таблиця 5 - Структура врожаю сортів озимої пшениці залежно від умов вирощування

\begin{tabular}{|c|c|c|c|c|}
\hline 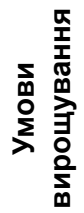 & 흥 & 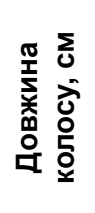 & 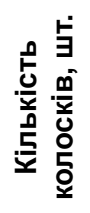 & 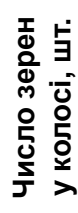 \\
\hline \multirow{5}{*}{ 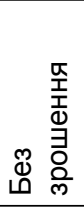 } & Одеська 267 & 8,0 & 20 & 31,0 \\
\hline & Таня еліта & 7,8 & 18 & 33,0 \\
\hline & Калим еліта & 7,4 & 17 & 33,5 \\
\hline & Баграт (еліта) & 7,2 & 15 & 30,5 \\
\hline & Дріада 1 & 7,6 & 16 & 30,9 \\
\hline \multirow{5}{*}{ 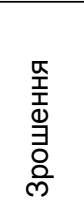 } & Одеська 267 & 10,8 & 21 & 37,5 \\
\hline & Таня еліта & 10,4 & 16 & 39,0 \\
\hline & Калим еліта & 10,2 & 18 & 38,7 \\
\hline & Баграт (еліта) & 10,8 & 16 & 39,4 \\
\hline & Дріада 1 & 10,6 & 15 & 33,7 \\
\hline
\end{tabular}

Таблиця 6 - Урожайність сортів озимої пшениці за різних умов вирощування

\begin{tabular}{|c|c|c|c|c|}
\hline \multirow{2}{*}{ 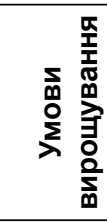 } & \multirow[b]{2}{*}{ ㅎํㅇ } & \multirow{2}{*}{ 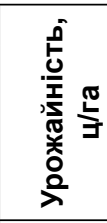 } & \multicolumn{2}{|c|}{ Відхилення } \\
\hline & & & $\frac{\pi}{3}$ & ¿ \\
\hline \multirow{5}{*}{ 营 } & Одеська 267 & 28,3 & - & - \\
\hline & Таня еліта & 26,9 & $-1,4$ & $-4,9$ \\
\hline & Калим еліта & 30,3 & $+2,0$ & $+7,1$ \\
\hline & Баграт (еліта) & 31,6 & $+3,3$ & $+11,7$ \\
\hline & Дріада 1 & 27,5 & $-0,8$ & $-2,8$ \\
\hline \multirow{5}{*}{ 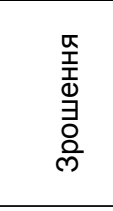 } & Одеська 267 & 57,9 & - & - \\
\hline & Таня еліта & 56,1 & $-1,8$ & $-3,1$ \\
\hline & Калим еліта & 59,4 & $+1,5$ & $+2,6$ \\
\hline & Баграт (еліта) & 60,7 & $+2,8$ & $+4,8$ \\
\hline & Дріада 1 & 56,4 & $-1,5$ & $-2,6$ \\
\hline $\mathrm{HIP}_{05}$ & & \multicolumn{3}{|c|}{$\begin{array}{l}\text { Для фактору } A-2,71 ; \\
\text { для фрактору B - 0,30; } \\
\text { взаємодія факторів } \\
A B-2,93 \text {. }\end{array}$} \\
\hline
\end{tabular}

Аналіз даних табл. 5 свідчить, що умови вирощування значно впливали на структуру урожаю озимої пшениці.

Елементи продуктивності головного колосу знаходяться у відповідній залежності від умов вирощування. Так, за зрошення довжина колосу збільшується в середньому від 2,8 см (у сорту Одеська 267) до 3,6 см (у сорту Баграт еліта) порівняно з умовами без зрошення.

Нами не встановлено значного впливу умов вирощування на кількість колосків головного колоса.

Найбільшу вагу зерна з колосу в умовах зрошення мали сорти Калим еліта (1,40 г) та Баграт еліта (1,42 г). Це більше, ніж у стандарту, відповідно на 0,10 та 0,12 г.

Вплив умов вирощування на рівень урожайності сортів озимої пшениці представлено в табл. 6.

Аналізуючи отримані результати, видно, що найбільшу врожайність як за умов без зрошення, так і за зрошення мали сорти Баграт та Калим. Ці сорти значно переважали стандарт Одеська 267. Так, сорт Баграт за умов без зрошення формував урожайність на рівні 31,6 ц/га, за умов зрошення - 60,7 ц/га.

Висновки. Порівняльна оцінка сортів озимої пшениці останніх сортозмін за рівнем їх екологічної стійкості, критеріїв адаптивної системи оптимізації сортового складу дала змогу встановити різний ступінь інтенсивності генетично і біологічно різнорідних сортів, що дає змогу ефективно використовувати агроекологічний потенціал кожної зони. У статті зроблено теоретичне узагальнення та нове вирішення завдання підвищення продуктивності озимої пшениці на основі добору найкращих взаємодоповнюючих сортів в умовах конкретного регіону.

\section{СПИСОК ВИКОРИСТАНОЇ ЛІТЕРАТУРИ:}

1. Базалій В. Принципи адаптивної селекції озимої пшениці в зоні південного Степу. Херсон : Айлант, 2004. 244 c.

2. Бондаренко В., Артюр О., Хмара В. Морозостійкість, зимостійкість і врожай озимої пшениці в залежності від умов зволоження і живлення рослин. Вісник сільськогосподарської науки. 1975. № 10. С. 22-26.

3. Литвиненко М. Теоретичні основи та методи селекції озимої м'якої пшениці на підвищення адаптивного потенціалу для умов Степу України : автореф. дис. ... д-ра с.-г. наук : 06.01.05. Київ, 2001. 46 с.

4. ОрлюкА., Усик Л. Мінливість сортів озимої м'якої пшениці за морфометричними ознаками. Таврійський науковий вісник. 2004. № 34. С. 194-201.

\section{REFERENCES:}

1. Bazalii, V.V. (2004). Principles of adaptive breeding of winter wheat in the Southern Steppe Zone. [Principles of adaptive breeding of winter wheat in the Southern Steppe Zone] Kherson: Ailant. [In Ukrainian]. 244 s.

2. Bondarenko, V.I., Artiur, O.D., \& Khmara, V.V. (1975). Winter wheat frost resistance, winter hardiness and yields depending on moisture conditions and plant feeding. [Winter wheat frost resistance, winter hardiness and yields depending on moisture conditions and plant feeding] Bulletin of agricultural science, 10, s. 22-26. [In Ukrainian].

3. Lytvynenko M.A. (2001). Theoretical foundations and methods of breeding soft winter wheat to increase its adaptive potential for the conditions of the Ukrainian. [Theoretical foundations and methods of breeding soft winter wheat to increase its adaptive potential for the conditions of the Ukrainian.] authors ref. dis. for science. degree of Doctor of Agricultural Sciences: Kyiv, 2001. $46 \mathrm{~s}$. [In Ukrainian].

4. Orlyuk A.P., Usik L.O. (2004) Variability of winter soft wheat varieties by morphometric characteristics [Variability of winter soft wheat varieties by morphometric characteristics] II Tavriya Scientific Bulletin. Kherson. Vip. 34. S. 194-201. [In Ukrainian].

Берднікова О.Г., Кучерак Е.М. Дослідження продуктивності сортового складу пшениці озимої в умовах Південного Степу України

Упровадження нових сортів озимої пшениці у виробництво - шлях до збільшення рентабельності її вирощування Озима пшениця - основна продовольча культура в нашій державі. Саме ії врожайність і рентабельність 
вирощування значною мірою визначають ступінь добробуту сільськогосподарських товаровиробників. На превеликий жаль, середня врожайність цієї культури в Україні в 2,5 рази нижча, ніж у країнах Західної Європи. Такий стан речей зумовлений багатьма чинниками, одним з яких $\epsilon$ використання для посівів насіння невисоких репродукцій та застарілих сортів, що не відповідають сучасним вимогам високоінтенсивного землеробства. Маневрування у сортовій структурі посівів дає позитивні результати. Сортовий склад посівів на кожний наступний рік формується виходячи із зареєстрованих та перспективних сортів і гібридів, але в кожному окремому господарстві може використовуватися лише частина з них. Одним з основних напрямів селекції високоврожайних сортів пшениці $є$ зменшення висоти стебла. Це зумовлено не лише потребою підвищення стійкості рослин проти вилягання, а й тенденцією збільшення врожаїв зерна за рахунок урожаїв соломи Досить високі врожаї нових інтенсивних сортів пшениці можна мати за загущеного стеблостою, збільшення кількості зерен у колоску, а також за підвищення вмісту білка в зерні. Різноманітністю кліматичних умов в Україні пояснюється те, що в західних областях із м'якими зимами і більшою кількістю опадів високі врожаї дають пізньостиглі сорти західноєвропейського екологічного типу.

Мета. Основною метою досліджень було визначення продуктивності сортів пшениці озимої як в умовах зрошення, так і без зрошення.

Методи. Використовувалися загальноприйняті методи досліджень - польовий і лабораторний, а саме:

- візуальний і вимірювально-ваговий - для спостереження за фазами розвитку та визначення біометричних показників рослин, їх продуктивності;

- біохімічний - для визначення якісних показників;

- гіпотез, аналізу, синтезу, абстрагування - під час формулювання мети та завдань досліджень, узагальнення одержаних результатів і обґрунтування висновків;

- математично-статистичний - для оцінки достовірності отриманих результатів досліджень;

Висновки. У статті розкрито теоретичне узагальнення та нове вирішення завдання підвищення продуктивності озимої пшениці на основі добору найкращих взаємодоповнюючих сортів в умовах конкретного регіону.

Ключові слова: озима пшениця, сорт, якість зерна, стійкість до хвороб, висота рослин, зимостійкість, урожайність, міжфазний період, вегетація, густота посіву, морфобіотип рослин.

Berdnikova O.G., Kucherak E.M. Research on the impact of the varietal composition of winter wheat under conditions of the Southern Steppe of Ukraine

Implementation of new winter wheat varieties into production is a way to increase profitability of cultivation.
Winter wheat is a main food crop in our country. The productivity and profitability of winter wheat production mainly determines the level of welfare of agricultural commodity producers. Unfortunately, the average productivity of this crop in Ukraine is two and a half times lower than that of the countries of Western Europe. This situation is caused by many factors, one of which is the use of seeds of low generations for sowing and obsolete varieties, that do not meet modern requirements of highly intensive agriculture. Flexibility in the crop varietal structure has positive results. The crop varietal composition is formed for the following year on the basis of registered and promising varieties and hybrids, but only a part of them can be used on each individual farm. One of the main areas of selection of high-yielding varieties of wheat is to reduce the height of the stem. This is due not only to the need to increase the resistance of plants against lodging, but also the tendency to increase grain yields due to straw yields. Quite high yields of new intensive varieties of wheat can be obtained with thickened stems, increasing the number of grains in the ear, as well as increasing the protein content in the grain. The variety of climatic conditions in Ukraine explains the fact that in the western regions with mild winters and more rainfall, high yields are given by late-ripening varieties of Western European ecological type.

Goal. The main purpose of the research was to determine the productivity of winter wheat varieties both under irrigation and without irrigation.

Methods. Common methods of field and laboratory research were used, namely:

- visual and measuring-weight - to monitor the phases of development and determine the biometric indicators of plants, their productivity;

- biochemical - to determine quality indicators;

- hypotheses, analysis, synthesis, abstraction in formulating the purpose and objectives of research, generalization of theresultsand substantiation of conclusions;

- mathematical and statistical - to assess the reliability of the obtained research results.

Conclusions. The article reveals a theoretical generalization and a new solution to the problem of increasing the productivity of winter wheat based on the selection of the best complementary varieties in a particular region.

Key words: winter wheat, variety, grain quality, disease resistance, plant height, tilling capacity, winter hardiness, interphase period, vegetation, sowing density, plant morphobiotype. 